By Celeste Amorim Varum and Vera Rocha. Accepted for publication by International Business Review. (under revision).

\title{
DO FOREIGN AND DOMESTIC FIRMS BEHAVE ANY DIFFERENT DURING ECONOMIC SLOWDOWNS? ${ }^{1}$
}

The global crisis has called to further reflection on the role of multinationals in host economies during crisis. The evidence on this matter is scarce and no definite conclusions were achieved. Using panel data analysis, this paper examines the link between foreign ownership, firm employment and turnover growth over twenty years and during economic downturns in particular. We analyse the determinants of firm employment and turnover growth and investigate whether there are significant differences in both variables among domestic and foreign firms when controlling for firm and industry specificities. Additionally we assess if the foreignness effect alters during economic downturns. After controlling for several firm and industry characteristics, we find no significant differences between domestic and foreign firms in what concerns employment growth. However, our results suggest that foreign ownership may affect positively firms' sales turnover growth during recessions.

Keywords: Foreign firms; economic crisis; employment and turnover growth; manufacturing; Portugal.

\footnotetext{
${ }^{1}$ We acknowledge DGEEP for allowing the use of the original data. The data analysis, results and conclusions of this study are of the authors' own responsibility. DGEEP stands for Direcção Geral de Estudos, Estatística e Planeamento from MTSS. The Ministry was created in 1916 as Ministry of Labour and Social Welfare. Now it is called Ministry of Labour and Social Solidarity (MTSS).
} 
By Celeste Amorim Varum and Vera Rocha. Accepted for publication by International Business Review. (under revision).

\section{INTRODUCTION}

Governments commonly seem to view inward foreign direct investment (FDI) and foreign presence as highly desirable (Oxelheim and Ghauri, 2004; Markusen and Nesse, 2007). However, the global financial and economic crisis, which struck most of the world's national and regional economic systems in the late 2007, has led to calls for further reflection on the role played by multinational enterprises (MNEs) in host economies. Do MNEs' activities contribute to the severity of global economic crisis or otherwise allow to mitigating some of the worst effects, by reducing lay-offs and output contraction in the host countries?

There is a debate on the role of MNEs in face of a crisis and the respective impact in host economies. MNEs can either help to alleviate the crisis' effects owing to their ownership advantages and their consequent superior performance, or add to macroeconomic instability due to the easiness with which they can transfer production facilities from one country to another. The empirical evidence on these matters is still scarce, strongly based on the context of the Asian financial crisis, and no definite conclusions were hitherto achieved.

In this paper we aim at filling this gap by addressing two research questions. First, we investigate if foreign ownership contributes to differentiate firm growth in terms of employment and turnover growth rates $^{2}$ during periods of crisis. Second, we analyse the influence of firm size and how it interferes with the foreign ownership effect during crises.

The mixed evidence on the impact of MNEs during crises may be partly explained by their investment motivations in a specific host economy along with the crisis' specificities. So, a study applied to a specific country, rather than a cross-national study, seems to be more appropriate to reach our purposes. Using panel data models, we test whether foreign firms (FF) acted as (un) stabilizer agents throughout recessions. The study covers the period 19882007 during which Portugal faced two economic slowdowns (early 1990s and early 2000s).

\footnotetext{
2 There are several measures of firm growth used the in literature, such as employment, turnover and profits. Turnover and sales are frequently used interchangeably in the literature (Coad, 2009; Bamiatzi, Bozos and Nikolopoulos, 2010).
} 
By Celeste Amorim Varum and Vera Rocha. Accepted for publication by International Business Review. (under revision).

The data is from Quadros de Pessoal, a rich and comprehensive dataset covering all firms employing paid labour. To the best of our knowledge, this is the first in-depth empirical study of this issue using a long time span using micro data for Portugal, a country with great challenges for convergence and with an active policy towards inward FDI. Our results contribute for the literature on the MNEs' role during crises by providing evidence of the Portuguese experience.

The paper is structured as follows. Section 2 reviews the most relevant literature on this matter. Section 3 relates to the empirical analysis, where data, variables and methodology are outlined and the results are discussed. Section 4 concludes and raises policy implications.

\section{MULTINATIONALS, HOST ECONOMIES AND ECONOMIC CRISIS}

MNEs are said to possess firm-specific advantages that make them able to surpass the liability of foreignness (Zaheer, 1995) and to outperform their domestic counterparts in the host economy (Hymer, 1976; Dunning and Lundan, 2008; Caves, 1996). What needs further research is whether under a crisis environment MNEs are affected or react in a different way from domestic firms (DFs). They may be in a better position to compete, and, therefore, resist better in terms of employment and sales during recessions.

The empirical results on this question are not unanimous. One first group of studies shows that MNEs can be a stabilizer agent, by attenuating the negative effects of crises. A second group supports that MNEs react to crisis periods more abruptly, worsening the crisis' impact on host economies. A third set of studies found no differences between foreign and domestic firms' growth during crises. Table 1 shows a summary of the main empirical studies on these matters.

Available firm-level studies have typically been based on Asian financial crisis of 19971998, dealing with firms' responses either during or after crisis, looking at several different 
By Celeste Amorim Varum and Vera Rocha. Accepted for publication by International Business Review. (under revision).

variables. In this paper, we are interested in firms' employment growth and turnover growth ${ }^{3}$ during crises. In the next sections we review this literature and derive our research questions.

\subsection{MNEs as a stabilizing agent}

A number of studies have found MNEs to exhibit a better reaction to crises than DFs, and also recover faster after crises (e.g. Athukorala, 2003; Narjoko and Hill, 2007). Several reasons may explain this pattern. One group of reasons relates to MNEs' ownership advantages, which include financial, knowledge and technological advantages, and advantages acquired through multinationality. Owing to these advantages, MNEs may be in a better position to compete and to face the obstacles in the market. For example, MNEs may have better access to resources, or the ability to use internal capital markets when faced with financial constraints, and be able to access overseas credit through their parent companies, which allows them to expand their economic activity even in turbulent periods (Desai et al., 2004; Blalock et al., 2005; Chung and Beamish, 2005).

The different reaction may also be related with the investment motivations of the foreign firms. If these are less reliant on local markets, and normally they are, they may be better able to lessen the adverse impact of a negative demand shock (Álvarez and Görg, 2007). Foreign firms are also unlikely to reply aggressively to short term changes in host country conditions as investing abroad involves substantial sunk costs (McAleese and Counahan, 1979), strong investment in long-term relationships or the accumulation of firmspecific skills (Fukao, 2001; Wang et al. 2005), which make them prefer to adapt themselves to the new environment by restructuring current operations, relieving excess capacity and maintaining their resources within the country (Gao and Eshaghoff, 2004).

\footnotetext{
${ }^{3}$ Employment growth and sales turnover growth are frequently used as measures of firm growth. Turnover and sales are frequently used interchangeably in the literature (Coad, 2009; Bamiatzi, Bozos and Nikolopoulos, 2010).
} 
By Celeste Amorim Varum and Vera Rocha. Accepted for publication by International Business Review. (under revision).

\subsection{MNEs as unstabilizer agent}

An important set of studies found MNEs to react more abruptly to economic recessions than DFs. This may happen because it is easier for them to transfer production facilities internationally (Flamm, 1984 ${ }^{4}$; Görg and Strobl, 2003; Lee and Makhija, 2009), to cut operational costs (Gao and Eshaghoff, 2004), to switch their sales from host countries to export markets (Lipsey, 2001), and, in the limit, to exit the local economy if the market and/or production conditions are less attractive (Álvarez and Görg, 2009). These reactions accelerate job losses, output contractions and the decline in business activities, making the subsequent recovery process more difficult. The MNEs' responses to changes in the economic environment are thought to depend also on the affiliates' position in the MNEs' network (Belderbos and Zou, 2007) or even on the country of origin, since Western MNEs were found to often adopt a "stop-and-go" approach, whereas Japanese ones tend to be more conservative (Legewie, 1999; Min et al., 2007).

\subsection{Foreign ownership as a neutral characteristic}

Finally, a number of studies found no significant differences between FFs and DFs in what concerns their reactions to crises (e.g. McAleese and Counahan (1979) for Ireland and Álvarez and Görg (2007) for Chile). These authors found both groups of firms to display identical patterns of reaction when accounting for various firm and industry-level specificities. McAleese and Counahan (1979), Álvarez and Görg (2007) and Wang et al. (2005) investigated further the interaction between ownership and size. While the first found large MNEs to have registered less job losses than other firms, the other two more recent studies found no difference among MNEs of different size.

\footnotetext{
${ }^{4}$ Flamm's argument is based on optimal portfolio theory, saying that when there are negative changes in the economy, foreign investors react and readjust their optimal portfolio and may thus leave the economy.
} 
By Celeste Amorim Varum and Vera Rocha. Accepted for publication by International Business Review. (under revision).

Table 1. Summary of firm-level empirical studies on the MNEs' potential stabilizer role

\begin{tabular}{|c|c|c|c|c|c|c|}
\hline $\begin{array}{l}\text { Main } \\
\text { Focus }\end{array}$ & Reference & $\begin{array}{l}\text { Country/Period } \\
\text { of Data }\end{array}$ & Crisis' Context & Methodology & $\begin{array}{l}\text { Firm Performance } \\
\text { Measure }\end{array}$ & $\begin{array}{l}\text { Potential } \\
\text { impact of } \\
\text { MNEs }\end{array}$ \\
\hline \multirow{9}{*}{$\begin{array}{l}\text { How do } \\
\text { firms } \\
\text { behave } \\
\text { during } \\
\text { crisis } \\
\text { periods? }\end{array}$} & $\begin{array}{l}\text { McAleese and } \\
\text { Counahan (1979) }\end{array}$ & Ireland / 1952-1977 & $\begin{array}{l}\text { Irish recession } \\
1973-1977\end{array}$ & $\begin{array}{l}\text { Chi-square tests; } \\
\text { Pearson correlations; } \\
\text { Contingency tables }\end{array}$ & Employment growth & $\leftrightarrow$ \\
\hline & Fukao (2001) & $\begin{array}{l}\text { 5 Asian countries / } \\
\text { 1996/1997 }\end{array}$ & $\begin{array}{l}1997 \text { East Asian } \\
\text { financial crisis }\end{array}$ & OLS and Tobit & $\begin{array}{l}\text { Growth of } \\
\text { employment, sales and } \\
\text { profits }\end{array}$ & $\uparrow$ \\
\hline & \multirow{2}{*}{$\begin{array}{l}\text { Görg and Strobl } \\
(2003)\end{array}$} & \multirow[b]{2}{*}{ Ireland / 1973-1996 } & \multirow{2}{*}{$\begin{array}{l}\text { Sector-specific } \\
\text { cycle }\end{array}$} & \multirow{2}{*}{$\begin{array}{l}\text { Cox Proportional } \\
\text { Hazard Model }\end{array}$} & Firm survival & $\downarrow$ \\
\hline & & & & & $\begin{array}{l}\text { Employment } \\
\text { persistence }\end{array}$ & $\uparrow$ \\
\hline & $\begin{array}{l}\text { Gao and } \\
\text { Eshaghoff (2004) }\end{array}$ & Argentina / 2002 & $\begin{array}{l}\text { Argentine Financial } \\
\text { Crisis (2001/2002) }\end{array}$ & $\begin{array}{l}\text { Exploratory factor } \\
\text { analysis }\end{array}$ & Business strategies & $\uparrow$ \\
\hline & Wang et al. (2005) & $\begin{array}{l}4 \text { ASEAN countries } \\
\text { / 1996/1998 }\end{array}$ & $\begin{array}{l}1997 \text { East Asian } \\
\text { financial crisis }\end{array}$ & $\begin{array}{l}\text { Logit and descriptive } \\
\text { statistics }\end{array}$ & $\begin{array}{l}\text { 1996-1998 } \\
\text { performance change }\end{array}$ & $\uparrow$ \\
\hline & $\begin{array}{l}\text { Álvarez and Görg } \\
\text { (2007) }\end{array}$ & Chile / 1990-2000 & $\begin{array}{l}\text { Chilean Economic } \\
\text { Crisis 1995-2000 }\end{array}$ & $\begin{array}{l}\text { Difference-in- } \\
\text { differences; Heckman } \\
\text { 2-step estimation } \\
\end{array}$ & Employment growth & $\leftrightarrow$ \\
\hline & $\begin{array}{l}\text { Belderbos and Zou } \\
(2007)\end{array}$ & $\begin{array}{l}9 \text { Asian Countries / } \\
1995-1999 \\
\end{array}$ & $\begin{array}{l}1997 \text { East Asian } \\
\text { financial crisis }\end{array}$ & $\begin{array}{l}\text { Probit; Heckman 2- } \\
\text { step estimation } \\
\end{array}$ & Employment growth & $\uparrow \downarrow$ \\
\hline & $\begin{array}{l}\text { Álvarez and Görg } \\
\text { (2009) }\end{array}$ & Chile / 1990-2001 & $\begin{array}{l}\text { Chilean Economic } \\
\text { Crisis 1995-2001 }\end{array}$ & Probit & Firm survival & $\downarrow$ \\
\hline \multirow{6}{*}{$\begin{array}{l}\text { How do } \\
\text { firms } \\
\text { behave } \\
\text { after } \\
\text { crisis } \\
\text { periods? }\end{array}$} & $\begin{array}{l}\text { Poon and } \\
\text { Thompson (2001) }\end{array}$ & $\begin{array}{l}\text { Hong-Kong and } \\
\text { Singapore / } 1998\end{array}$ & $\begin{array}{l}1997 \text { East Asian } \\
\text { financial crisis }\end{array}$ & $\begin{array}{l}\text { Descriptive statistics; } \\
\text { ANOVA }\end{array}$ & $\begin{array}{l}\text { MNCs' embeddedness } \\
\text { and expectations }\end{array}$ & $\uparrow$ \\
\hline & Athukorala (2003) & $\begin{array}{l}5 \text { ASEAN countries } \\
\text { / 1990-2001 }\end{array}$ & $\begin{array}{l}1997 \text { East Asian } \\
\text { financial crisis }\end{array}$ & Descriptive Statistics & $\begin{array}{l}\text { Employment and } \\
\text { output }\end{array}$ & $\uparrow$ \\
\hline & $\begin{array}{l}\text { Blalock et al. } \\
\text { (2005) }\end{array}$ & $\begin{array}{l}\text { Indonesia / 1990- } \\
2000\end{array}$ & $\begin{array}{l}1997 \text { East Asian } \\
\text { financial crisis }\end{array}$ & $\begin{array}{l}\text { Difference-in- } \\
\text { differences; Probit }\end{array}$ & $\begin{array}{l}\text { Value added, } \\
\text { employment, } \\
\text { investment and } \\
\text { survival }\end{array}$ & $\uparrow$ \\
\hline & $\begin{array}{l}\text { Chung and } \\
\text { Beamish (2005) }\end{array}$ & $\begin{array}{l}5 \text { ASEAN countries } \\
\text { / 1986-2001 }\end{array}$ & $\begin{array}{l}1997 \text { East Asian } \\
\text { financial crisis }\end{array}$ & $\begin{array}{l}\text { Logit; Multivariate } \\
\text { analysis; Cox PHM }\end{array}$ & $\begin{array}{l}\text { Firm strategy and firm } \\
\text { survival }\end{array}$ & $\uparrow$ \\
\hline & Min et al. (2007) & Korea / 1997-2001 & $\begin{array}{l}1997 \text { East Asian } \\
\text { financial crisis }\end{array}$ & $\begin{array}{l}\text { GLS and forecasting } \\
\text { techniques }\end{array}$ & $\begin{array}{l}\text { Number and value of } \\
\text { FDI projects }\end{array}$ & $\uparrow \downarrow$ \\
\hline & $\begin{array}{l}\text { Narjoko and Hill } \\
(2007)\end{array}$ & $\begin{array}{l}\text { Indonesia / 1993- } \\
2000\end{array}$ & $\begin{array}{l}1997 \text { East Asian } \\
\text { financial crisis }\end{array}$ & $\begin{array}{l}\text { OLS; Probit; } \\
\text { Heckman 2-step } \\
\text { estimation }\end{array}$ & $\begin{array}{l}\text { Real Value Added and } \\
\text { firm survival }\end{array}$ & $\uparrow$ \\
\hline \multirow{5}{*}{$\begin{array}{c}\text { How do } \\
\text { firms } \\
\text { behave } \\
\text { during } \\
\text { and } \\
\text { after } \\
\text { crisis } \\
\text { periods? }\end{array}$} & Legewie (1999) & $\begin{array}{l}\text { Southeast Asia } \\
\text { countries / 1990s } \\
\end{array}$ & $\begin{array}{l}1997 \text { East Asian } \\
\text { financial crisis }\end{array}$ & $\begin{array}{l}\text { Descriptive statistics } \\
\text { and case studies }\end{array}$ & $\begin{array}{l}\text { Market orientation and } \\
\text { internal structure }\end{array}$ & $\uparrow \downarrow$ \\
\hline & $\begin{array}{l}\text { Edgington and } \\
\text { Hayter (2001) }\end{array}$ & $\begin{array}{l}5 \text { ASEAN countries } \\
\text { / 1990s }\end{array}$ & $\begin{array}{l}1997 \text { East Asian } \\
\text { financial crisis }\end{array}$ & $\begin{array}{l}\text { Descriptive statistics } \\
\text { and case studies }\end{array}$ & $\begin{array}{l}\text { Investments and } \\
\text { Exports }\end{array}$ & $\uparrow$ \\
\hline & Lipsey (2001) & $\begin{array}{l}\text { Latin America, } \\
\text { Mexico and East } \\
\text { Asia / 1980s and } \\
\text { 1990s }\end{array}$ & $\begin{array}{l}\text { Crisis in Latin } \\
\text { America (1982), } \\
\text { Mexico (1994) and } \\
\text { East Asia (1997) }\end{array}$ & Descriptive statistics & $\begin{array}{l}\text { Employments, sales } \\
\text { and exports }\end{array}$ & $\downarrow$ \\
\hline & Desai et al. (2004) & $\begin{array}{l}25 \text { emerging } \\
\text { economies / 1991- } \\
1999\end{array}$ & $\begin{array}{l}\text { Currency } \\
\text { depreciation events }\end{array}$ & $\begin{array}{l}\text { Panel regression; IV; } \\
\text { Bivariate analysis }\end{array}$ & $\begin{array}{l}\text { Sales and assets (in } \\
\text { level and growth rates) }\end{array}$ & $\uparrow$ \\
\hline & $\begin{array}{l}\text { Takii and } \\
\text { Ramstetter (2005) }\end{array}$ & $\begin{array}{l}\text { Indonesia / 1975- } \\
2001\end{array}$ & $\begin{array}{l}1997 \text { East Asian } \\
\text { financial crisis }\end{array}$ & $\begin{array}{l}\text { Pooled regression; } \\
\text { Descriptive statistics }\end{array}$ & $\begin{array}{l}\text { Value added, } \\
\text { employment and } \\
\text { productivity }\end{array}$ & $\uparrow$ \\
\hline
\end{tabular}

$\uparrow$ - MNEs acted as a stabilizer element; $\downarrow$ - MNEs acted as a destabilizer element; $\uparrow \downarrow$ - Mixed results regarding MNEs' stabilizer role; $\leftrightarrow$ - No evidence of a (de)stabilizer role for MNEs 
By Celeste Amorim Varum and Vera Rocha. Accepted for publication by International Business Review. (under revision).

From the above, there seems to be no agreement on the foreign ownership effect under crises. The comparison across results should be done carefully as part of the differences may be related to the choice of the dependent variables (firm survival, employment, sales or turnover growth). This paper focuses on firms' employment growth and turnover growth during recessions. The previous studies were also conducted under different crisis' contexts.

The way MNEs react to a domestic shock seems very much linked to their investment motivations and the crisis' context. In what regards market-seeking foreign firms, their sales and employment will be severely hit from a shock in demand, but not in a particularly different way from DFs. They may, however, resist better due to their superior financial conditions and better expectations about the future. Nonetheless, if their long-term expectations in that market are not better than those of DFs, they may undercut their operations in the local economy.

MNEs established in a country mainly to have better access to resources or efficiency are probably more export-oriented than DFs. Hence, their sales and employment levels may be less affected than DFs' levels in a crisis' context. They may even benefit from a decline in the prices of inputs domestically to expand sales abroad. If the crisis is associated to a (domestic or global) rise in input prices, MNEs may react better than DFs if they are able to access inputs in better conditions than their indigenous counterparts. Otherwise, they may react more adversely by reconfiguring their local and/or global competitive strategies and hence redeploy their activities, motivated by better conditions elsewhere (Gao and Eshaghoff, 2004; Álvarez and Görg, 2007, 2009).

Finally, strategic asset-seeking MNEs are expected to be resilient during crises, due to potential sunk costs of their specific investments and/or the expectations of long-term benefits. We may raise these theoretical expectations from the literature, but they need to be empirically tested. 
By Celeste Amorim Varum and Vera Rocha. Accepted for publication by International Business Review. (under revision).

There are firm and industry characteristics likely to affect firm growth (Coad, 2009), and we must properly account for them in order to investigate if there remain significant differences on firm growth during recessions that can be attributed to foreignness per se.

\section{EMPIRICAL ANALYSIS}

\subsection{Empirical setting}

During this period, and mainly after the EEC accession in 1986, Portugal experienced an outstanding growth of FDI inflows (OECD, 1994). Over the period, FFs assumed a significant role in the modernization and dynamics of the Portuguese economy. According to Tavares (2002) and Barbosa et al. (2004), due to the country's location in Western Europe the relatively lower input costs and the export opportunities-were the main motivations for foreign entry and permanence, which shows the importance of both efficiency-seeking and, to a less scale, market-seeking motivations of MNEs. In manufacturing, the bulk of FFs is located in Portugal with the aim of benefiting from factor price differences between this small open economy and other countries in Europe, and, to a less extent, from a small but growing market.

During the period under analysis (1988-2007), the Portuguese economy experienced periods of considerable growth but also years of recession: the early 1990s (1991-1993) and 2000s (2001-2003). These were characterized by declines in GDP, private consumption and investment and an increase in unemployment (Figures 1 and 2). These recessions were associated to a decline in economic activity, which occurred mainly in developed countries, leading to considerable declines in Portuguese exports and in private consumption along with investment contraction. Nonetheless, internally, reductions in public investment and gross fixed capital formation, in addition to fragilities at total factor productivity also contributed to further declines in economic activity (Bank of Portugal, 2009a, 2009b). 
By Celeste Amorim Varum and Vera Rocha. Accepted for publication by International Business Review. (under revision).

Figure 1. Annual growth rate of Portuguese real GDP ${ }^{5}$

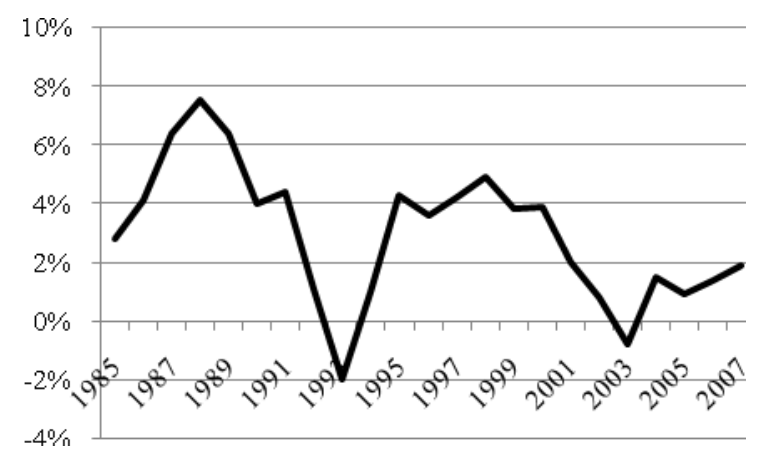

Figure 2. Unemployment rate in Portugal ${ }^{6}$

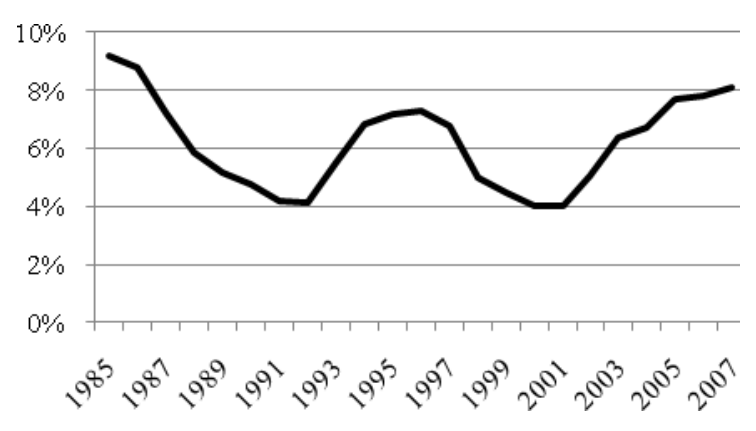

These recessions are likely to have affected firms' growth, but the effect may differ between firms. In this study we investigate in specific this phenomenon.

\subsection{Data}

The study uses data from Quadros de Pessoal (hereafter QP), a database from DGEEP of the Ministry of Labour and Social Solidarity ${ }^{7}$ that is based on a compulsory annual survey covering all firms with wage earners in Portugal, conducted since 1982. We worked with the original raw data files at the firm level from 1988 to 2007, which include over 100.000 firms each year. Data at 2-digit industry level (ISIC rev. 2) on exports and on Gross Value Added is from the National Institute of Statistics and the Bank of Portugal respectively.

\subsection{Model and variables}

Our empirical strategy went through three main steps. First, we investigated if foreign ownership affected firm growth (measured by employment growth and sales turnover growth) during recessions and to do so we used a similar equation to that used by Álvarez and Görg (2007):

$$
\ln \left(Y_{i t}\right)-\ln \left(Y_{i t-1}\right)=\alpha_{i}+Z_{i t}^{\prime} \delta+\gamma_{1} O w n_{i t}+\gamma_{2} \text { Down }+\gamma_{3} O w n_{i t}{ }^{*} D o w n+\varepsilon_{i t}
$$

\footnotetext{
${ }^{5}$ Source: OECD - Country Statistical Profiles 2009

${ }^{6}$ Source: OECD - Key Economic Indicators (KEI) Database

${ }^{7}$ We acknowledge DGEEP for allowing the use of the original data. The data analysis, results and conclusions are of the authors' own responsibility. DGEEP stands for Direcção Geral de Estudos, Estatística e Planeamento from MTSS. The Ministry was created in 1916 as Ministry of Labour and Social Welfare. Now it is called Ministry of Labour and Social Solidarity (MTSS).
} 
By Celeste Amorim Varum and Vera Rocha. Accepted for publication by International Business Review. (under revision).

where $Y$ is the proxy for growth of firm $i$ in each time period, corresponding to employment growth in a first specification and to sales turnover growth in a second specification. These variables are measured by the log difference in employment (and sales turnover) in firm $i$ between $t$ and $t-1$.

A dummy variable - Own - allows distinguishing between FFs and DFs, and Down is a dummy for the periods of recession. The overall effect of economic recessions is given by $\gamma_{2}$, which is expected to be negative. The equation evaluates the impact of being foreign-owned during recessions through an interaction term $-O w n * D o w n$. If FFs are more able to absorb recessions, the growth in these plants should be higher than for DFs in the recession period, and, in that case, $\gamma_{3}$ will be positive and significant. If $\gamma_{3}$ is negative, then FFs contract more than DFs during the crisis. If $\gamma_{3}$ is zero or non-significant, it indicates that there are no differences in the response between foreign and domestic firms.

$Z$ is a vector of firm and industry's characteristics ${ }^{8}$ that are likely to affect the dependent variables, according to the literature. We do not develop specific hypotheses regarding their effects but we will control for them. In particular, we include age and size, as both have been found in the literature to explain firm growth (Evans, 1987; Dunne and Hughes, 1994). We introduce the square of both variables, since their impact may be non-linear (Cardoso, 2008).

Labour productivity and firm's human capital characteristics may affect firms' performance, so they must also be accounted for. We recall that FFs are normally found more productive and more capital intensive than DFs (Álvarez and Görg, 2007, 2009). Firm location in urban centres may also impact upon firm growth and MNEs are agglomerated in the principal cities, aiming to profit from urbanization externalities (Guimarães et al., 2000). Industry attributes are also controlled for, namely minimum efficient scale, industry concentration, industry growth, international openness and foreign presence, which are the

\footnotetext{
${ }^{8}$ A table with a detailed description of variables can be found in the Appendix.
} 
By Celeste Amorim Varum and Vera Rocha. Accepted for publication by International Business Review. (under revision).

main industry-level variables commonly found in the literature to influence firm growth over time (e.g., Barbosa and Louri, 2005; Álvarez and Görg, 2007; Cardoso, 2008).

Considering the likely moderating effect of firm size upon foreign ownership, we run equation (1) using, separately, the whole sample and the samples of SMEs and large enterprises (LEs).

Our exploration of the size effect led us to estimate a second equation where all the variables are the same as in equation (1), with the exception of the interaction variables.

$$
\ln \left(Y_{i t}\right)-\ln \left(Y_{i t-1}\right)=\alpha_{i}+Z_{i t}^{\prime} \delta+\gamma_{1} \text { Own }_{i t}+\gamma_{2} \text { Down }+\gamma_{3} \text { Size }_{i t}{ }^{*} \text { Down }+\gamma_{4}
$$

Size ${ }_{i t}^{2}{ }^{*}$ Down $+\varepsilon_{i t}$

In equation (2) we test the effect of size, instead of ownership, during recessions (through the terms $\operatorname{Size}_{i t}{ }^{*}$ Down and $\operatorname{Size}_{i t}^{2}{ }^{*}$ Down). Since the relation between size and firm growth is frequently found to be non-linear we included the variable $\operatorname{Size}_{i t}$ and $\operatorname{Size}_{i t}{ }_{i t}$.

Finally, we estimate an equation for the sample of FFs, in order to investigate further the role of size within the group of MNEs' affiliates under recessions. $Z$ is the same vector of firm and industry's characteristics, but we test if being large-sized matters for differentiating among FFs and how it matters during recessions (through the terms Large $_{i t}$ and Large $_{i t} *$ Down):

$$
\ln \left(Y_{i t}\right)-\ln \left(Y_{i t-1}\right)=\alpha_{i}+Z_{i t}^{\prime} \delta+\gamma_{1} \operatorname{Large}_{i t}+\gamma_{2} \text { Down }_{+} \gamma_{3} \operatorname{Large}_{i t}{ }^{*} \text { Down }+\varepsilon_{i t}
$$

We applied panel data models ${ }^{9}$ to estimate all the above equations and, specifically, the suitability of within-groups and between-groups estimators. For all the estimations, Hausman test rejected the hypothesis of null covariance between the regressors and the individual effects, thus fixed effect estimators proved to be the most appropriate, being unbiased, consistent and asymptotical normal. In addition, our estimations were always applied to all firms in operation every year. Albeit many empirical studies often select a

\footnotetext{
${ }^{9}$ Panel data models allow us to assess firm growth measures longitudinally, rather than cross-sectionally. The literature points that crosssectional measurement of firm performance is insufficient and that it should be measured longitudinally, due to the importance of time dimension (e.g., Pfaffermayr and Bellak, 2002; Hult et al., 2008).
} 
By Celeste Amorim Varum and Vera Rocha. Accepted for publication by International Business Review. (under revision).

sample of only surviving firms, such a choice may bias the results in favour of foreign-owned firms if they present higher survival probabilities, leading to the conclusion that foreign ownership has a significant explanatory power upon firm performance measures (e.g., Álvarez and Görg, 2007). To avoid such a bias, we included in our estimations surviving and non-surviving firms during the period under analysis, which constituted an unbalanced panel. Estimations using a fixed-effects approach take this factor into account, so it does not represent any problem (Greene, 2008).

\subsection{Descriptive statistics}

Figure 3 shows the relative importance of $\mathrm{FFs}^{10}$ in the total number of firms, total employment and total sales turnover of Portuguese Manufacturing Industry (PMI). Our data shows that in 1988, FFs only represented 1.2 percent of total firms contributing, however, to 8 percent of total employment and 13 percent of total turnover in manufacturing. Between 1988 and 2007, FFs increased their share in manufacturing employment about 5 percentage points and their share of total turnover almost doubled.

Figure 3. Relative importance of FF in manufacturing ( $F F$ as percentage of the total)
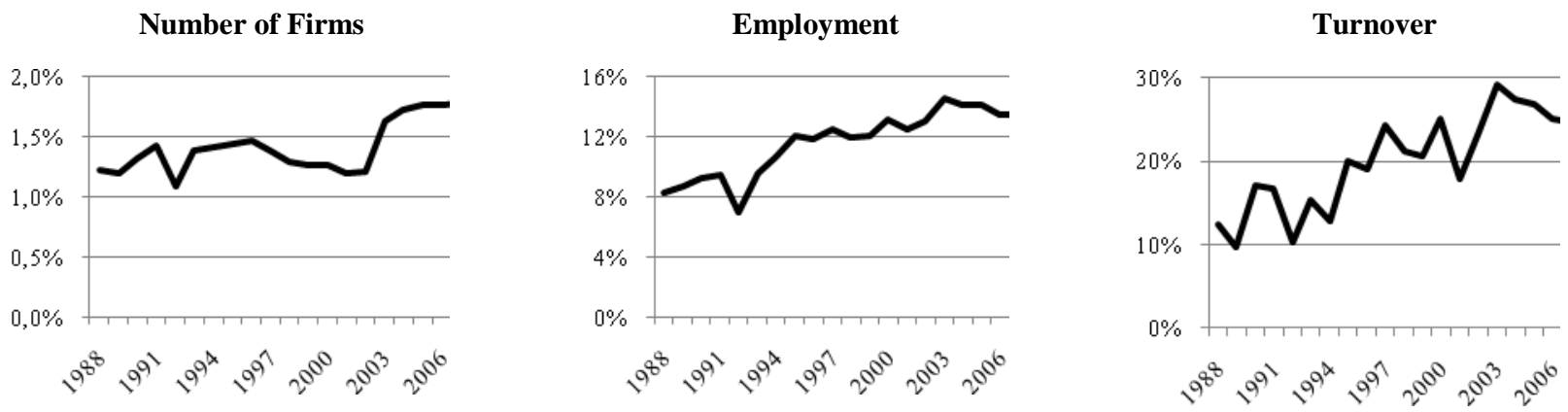

Figures 4 and 5 compare employment and turnover growth rates between domestic and foreign firms. FFs' employment grew on average $1,8 \%$, compared to a growth rate of $0.2 \%$ among DFs. The impact of crises in employment is evident for both groups: FFs registering a

\footnotetext{
${ }^{10}$ A firm was considered as foreign-owned firm if the share of foreign capital is at least, of 50\%, a participation level that ensures a significant intensity of foreign influence on domestic operations.
} 
By Celeste Amorim Varum and Vera Rocha. Accepted for publication by International Business Review. (under revision).

break of almost 12 percentage points in the employment growth rate between 1992 and 1993, and negative rates during the first half of 2000s. DFs show similar but smoother changes.

However, FFs seem to react first and more abruptly, but conversely, appear to recover faster.

In what concerns turnover, the average growth rates of turnover were $13 \%$ and $12 \%$ for FFs and DFs respectively. There was a reduction in FF s' (Plural) (singular) sales by 18 percentage points between 1992 and 1993 and a persistent decline over the period 2001-2006.

DFs' turnover growth has declined all over the period under analysis.

Figure 4. Employment Growth

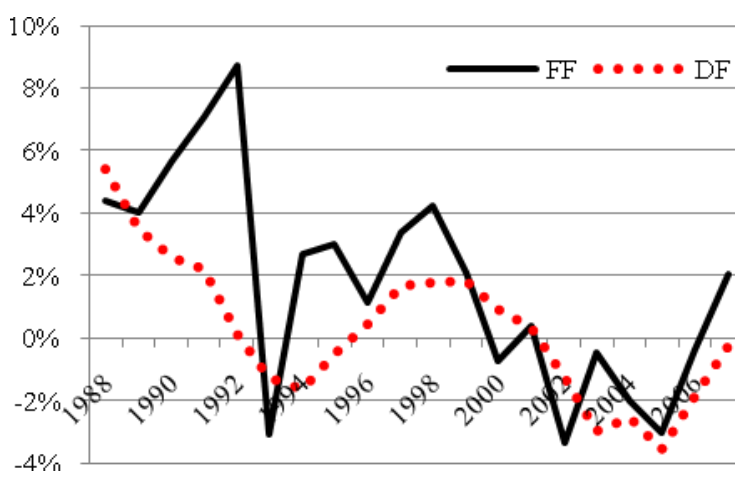

Figure 5. Turnover Growth

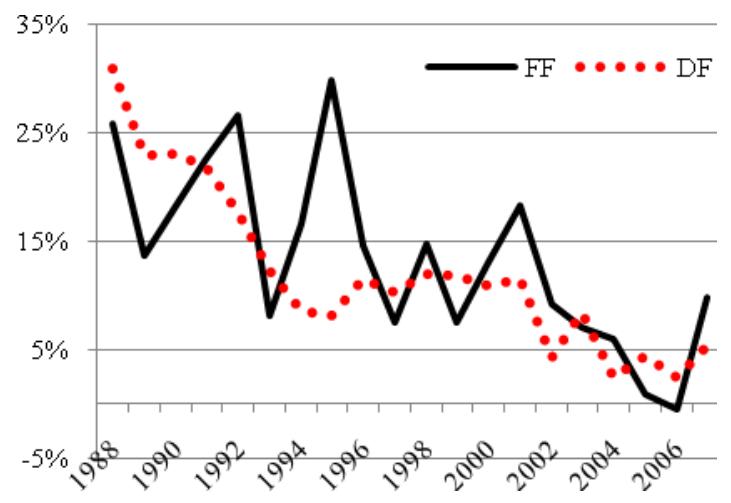

Figures 6 to 9 compare firms according to size. The distinction between SMEs and LEs is based on European definition ${ }^{11}$. The graphs show that, unconditionally, FFs were always more volatile than DFs. During the early 1990s recession, large DFs registered larger losses of employment while large FFs registered largest declines in turnover instead. During the second slowdown, there were larger job losses among SMEs (both foreign and domestic), while large FFs also registered largest declines in turnover.

These first statistics suggest that the cyclical downturns of Portuguese economy affected the growth of both sets of firms. In order to disentangle the effects of other covariates from

\footnotetext{
${ }^{11}$ According to the European definition, a firm is considered a SME if it employs fewer than 250 persons and if its annual turnover does not exceed 50 million euro or its balance sheet does not exceed 43 million euro:

http://ec.europa.eu/enterprise/enterprise_policy/sme_definition/sme_user_guide_pt.pdf
} 
By Celeste Amorim Varum and Vera Rocha. Accepted for publication by International Business Review. (under revision).

the effect of foreign ownership and firm size, in the next section we turn to an econometric modelling of the determinants of employment and turnover growth.

Figure 6. Employment Growth in SMEs

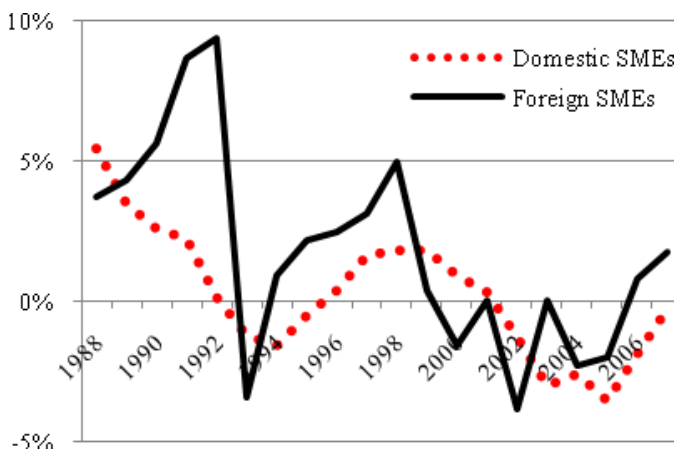

Figure 8. Employment Growth in LEs

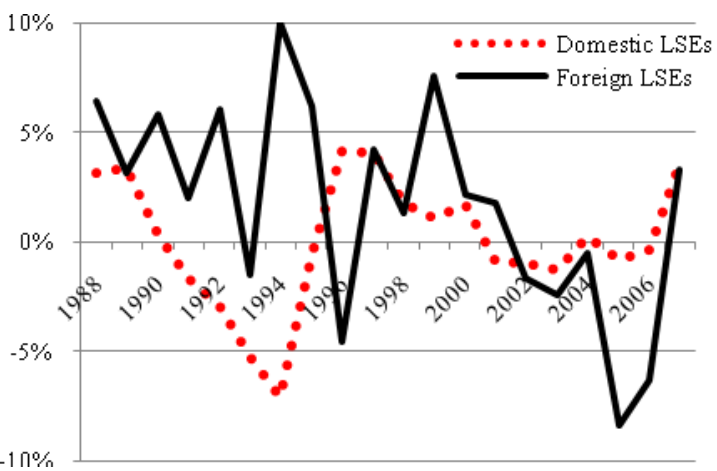

Figure 7. Turnover Growth in SMEs

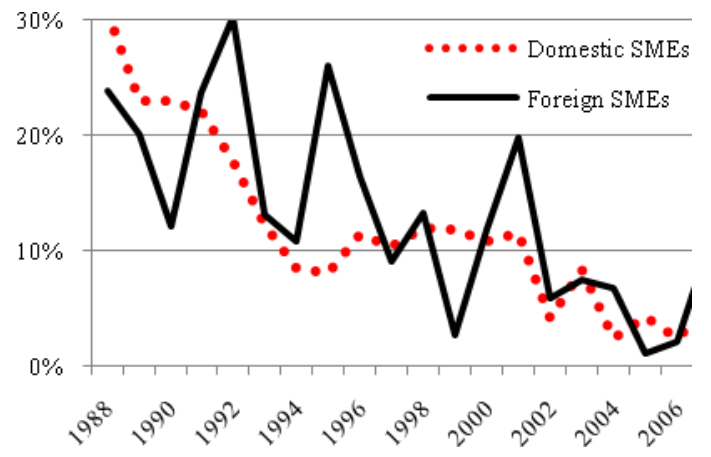

Figure 9. Turnover Growth in LEs

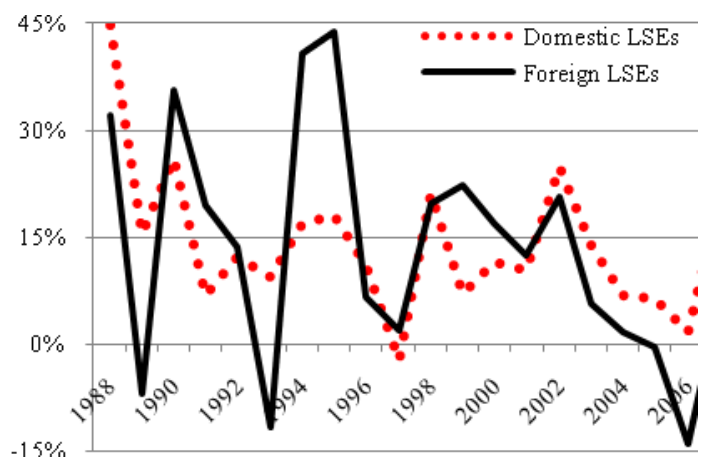

\subsection{Empirical results}

Table 2 shows the estimations for employment growth and Table 3 for turnover growth. In each, Models 1 and 2 correspond to the equations (1) and (2), without and with the size variable. In columns 3 and 4 we show the results of equation (1) applied separately to the samples of small and large enterprises respectively to further explore the ownership effect in interaction with size. Finally, column 5 shows the results of equation (3), testing the effects of size within the foreign firms' sample.

\subsubsection{Employment Growth}

Table 2 shows the results for employment growth over 1988-2007. Regarding the effect of firm-level variables, all are statistically significant. Firm age and size have a significant 
By Celeste Amorim Varum and Vera Rocha. Accepted for publication by International Business Review. (under revision).

inverted U-shaped effect upon employment growth, which means that young SMEs show positive trends on employment growth up to a certain threshold of size, maybe due to their nimbleness and need to reach a minimum efficient scale in order to compete with more mature and larger firms. Additionally, firms with higher operational performance and more human capital-intensive firms show slower employment growth rates.

When we control for firms' and industries' characteristics, foreign ownership, though with a negative coefficient, is not significant to explain differences in employment growth between firms. Regarding industries' attributes, firms in industries with lower concentration, higher export intensity and with greater foreign presence show higher employment growth over the period. Hence, firms' employment growth is an outcome of other firm and industry characteristics rather than a pure ownership effect (e.g., Karlsson et al., 2009).

The two recessions affecting the Portuguese economy impacted negatively on firms' employment growth (Downturn coefficient is negative and significant at $1 \%$ level), but not in a different fashion according to their ownership (Models A.1 and A.3, A.4). This result is in line with McAleese and Counahan (1979) and Álvarez and Görg (2007). Accordingly, we do not find evidence of a (un)stabilizer role played by FFs during recessions upon job losses.

Looking at the results of Model A.2, the crises' impact upon employment growth seems stronger for larger firms. Large enterprises may be the first to lay-off workers in order to reduce operational costs to thrive the crisis. Berry et al. (2001) and Tan and See (2004) also found evidence on SMEs' resistance during volatile macroeconomic conditions. Nevertheless, the effect of size is less visible among FFs, as large FFs' employment growth rates did not evolve significantly different from that of smaller FFs during the two recessions (Model A.5). Wang et al.'s (2005) study of firms' success during the Asian crisis also revealed that firm size was not significant to differentiate between foreign firms. 
By Celeste Amorim Varum and Vera Rocha. Accepted for publication by International Business Review. (under revision).

\subsubsection{Turnover Growth}

Table 3 reports the results for turnover growth. Considering the firm-level variables, as for employment growth, we find significant non-linear effects of firm's age and size. Larger firms tend to have better sales' performance although excessively large firms are affected by their inert and rigid nature. Turnover growth seems to lower during firms' infancy, growing faster only after firms attain a minimum age. Firms' operational performance impacts positively upon firms' turnover growth and, as for employment dynamics, firms with higher human capital intensity tend to have slower rates of growth at sales.

In what regards turnover growth during all the period, foreign ownership per se matters. Foreign firms show 10-15\% lower sales growth than their domestic partners.

The location in urban centres emerges as a positive factor for sales expansion, probably due to the proximity to a larger market. At industry-level, belonging to industries with higher MES, with greater concentration and lower foreign shares - thus, industries with higher entry barriers and greater potential for market gains - potentiate firms' turnover growth. Firms in more export-oriented industries tend to have slower turnover growth, probably due to higher competition in international markets.

The two economic recessions affected significantly the firms' turnover growth rate, but the effects seem to differ slightly between firms accordingly to ownership and size. The effect of being foreign-owned during recessions is positive (the coefficient of Own*Downturn is positive and significant in Models B.1 and B.3) as FFs reveal about 5\% higher sales growth rates during recessions compared with DFs. Our result is in line with that found by Fukao, 2001. Notwithstanding, the foreign ownership effect seems more significant among SMEs, but not so much for explaining differences between Les during recessions. 
By Celeste Amorim Varum and Vera Rocha. Accepted for publication by International Business Review. (under revision).

Table 2. Employment growth estimation results

\begin{tabular}{|c|c|c|c|c|c|c|c|c|c|c|}
\hline \multirow{3}{*}{ Constant } & \multirow{2}{*}{\multicolumn{2}{|c|}{$\begin{array}{c}\text { All Firms } \\
\text { Model A.1 } \\
\end{array}$}} & \multirow{2}{*}{\multicolumn{2}{|c|}{$\begin{array}{c}\text { All Firms } \\
\text { Model A.2 } \\
\end{array}$}} & \multirow{2}{*}{\multicolumn{2}{|c|}{$\begin{array}{c}\text { SMEs } \\
\text { Model A.3 }\end{array}$}} & \multirow{2}{*}{\multicolumn{2}{|c|}{$\begin{array}{c}\text { Les } \\
\text { Model A.4 } \\
\end{array}$}} & \multirow{2}{*}{\multicolumn{2}{|c|}{$\frac{\text { FF }}{\text { Model A.5 }}$}} \\
\hline & & & & & & & & & & \\
\hline & 0.5863 & $* * *$ & 0.5793 & $* * *$ & 0.6386 & $* * *$ & -5.6111 & $* * *$ & -0.8486 & $* * *$ \\
\hline & $(0.0139)$ & & $(0.0140)$ & & $(0.0141)$ & & $(0.2006)$ & & $(0.1127)$ & \\
\hline \multirow[t]{2}{*}{ Age } & 0.0002 & $* *$ & 0.0002 & $* *$ & 0.0002 & $* *$ & $-4.19 \mathrm{e}-05$ & & 0.0002 & \\
\hline & $(0.0001)$ & & $(0.0001)$ & & $(0.0001)$ & & $(0.0003)$ & & $(0.0006)$ & \\
\hline \multirow[t]{2}{*}{ Age squared } & $-7.36 e-08$ & $*$ & $-9.45 e-08$ & $* *$ & $-9.02 e-08$ & $* *$ & $1.01 \mathrm{e}-08$ & & $-7.70 e-08$ & \\
\hline & $(3.83 \mathrm{e}-08)$ & & $(3.84 \mathrm{e}-08)$ & & $(3.96 \mathrm{e}-08)$ & & $(1.55 \mathrm{e}-07)$ & & $(2.86 \mathrm{e}-07)$ & \\
\hline \multirow[t]{2}{*}{ Size } & 0.4594 & $* * *$ & 0.4615 & $* * *$ & 0.4715 & $* * *$ & 1.6917 & $* * *$ & 0.6537 & $* * *$ \\
\hline & $(0.0020)$ & & $(0.0021)$ & & $(0.0021)$ & & (0.0509) & & $(0.0211)$ & \\
\hline \multirow[t]{2}{*}{ Size squared } & -0.0358 & $* * *$ & -0.0359 & $* * *$ & -0.0405 & $* * *$ & -0.1176 & $* * *$ & -0.0431 & $* * *$ \\
\hline & $(0.0004)$ & & $(0.0004)$ & & $(0.0005)$ & & $(0.0043)$ & & $(0.0028)$ & \\
\hline \multirow[t]{2}{*}{ Firm Performance } & -0.1334 & $* * *$ & -0.1333 & $* * *$ & -0.1376 & $* * *$ & -0.0265 & $* * *$ & -0.1005 & $* * *$ \\
\hline & $(0.0007)$ & & $(0.0007)$ & & $(0.0007)$ & & $(0.0036)$ & & $(0.0043)$ & \\
\hline \multirow[t]{2}{*}{ Human Capital } & -0.1480 & $* * *$ & -0.1469 & $* * *$ & -0.1355 & $* * *$ & -0.0910 & & -0.0826 & $*$ \\
\hline & $(0.0083)$ & & $(0.0083)$ & & $(0.0084)$ & & $(0.0615)$ & & $(0.0496)$ & \\
\hline \multirow[t]{2}{*}{ Ownership } & -0.0034 & & -0.0073 & & -0.0016 & & -0.0204 & & & \\
\hline & $(0.0066)$ & & $(0.0062)$ & & $(0.0073)$ & & $(0.0157)$ & & & \\
\hline \multirow[t]{2}{*}{ Urban } & 0.0050 & & 0.0049 & & 0.0034 & & -0.1233 & $* * *$ & -0.0224 & \\
\hline & $(0.0076)$ & & $(0.0076)$ & & (0.0079) & & $(0.0323)$ & & $(0.0343)$ & \\
\hline \multirow[t]{2}{*}{ Large } & & & & & & & & & -0.0123 & \\
\hline & & & & & & & & & $(0.0224)$ & \\
\hline \multirow[t]{2}{*}{ Downturn } & -0.0043 & $* * *$ & -0.0069 & $* * *$ & -0.0036 & $* * *$ & -0.0300 & $* * *$ & -0.0260 & $* * *$ \\
\hline & $(0.0008)$ & & $(0.0021)$ & & $(0.0008)$ & & $(0.0075)$ & & $(0.0087)$ & \\
\hline \multirow[t]{2}{*}{ Own*Downturn } & -0.0099 & & & & -0.0107 & & 0.0036 & & & \\
\hline & $(0.0062)$ & & & & $(0.0070)$ & & $(0.0145)$ & & & \\
\hline \multirow[t]{2}{*}{ Size*Downturn } & & & -0.0055 & $* * *$ & & & & & & \\
\hline & & & $(0.0017)$ & & & & & & & \\
\hline \multirow[t]{2}{*}{ Size squared*Downturn } & & & 0.0001 & & & & & & & \\
\hline & & & $(0.0003)$ & & & & & & & \\
\hline \multirow[t]{2}{*}{ Large dummy*Downturn } & & & & & & & & & 0.0067 & \\
\hline & & & & & & & & & (0.0177) & \\
\hline MES & -0.0002 & & -0.0001 & & -0.0006 & & -0.0007 & & 0.0151 & $* * *$ \\
\hline & $(0.0005)$ & & $(0.0005)$ & & $(0.0006)$ & & $(0.0037)$ & & $(0.0050)$ & \\
\hline HH Index & -1.4719 & $* * *$ & -1.4975 & $* * *$ & -1.5668 & $* * *$ & 3.0606 & $* *$ & -5.3278 & $* * *$ \\
\hline & $(0.2105)$ & & $(0.2105)$ & & $(0.2139)$ & & $(1.3811)$ & & (1.6135) & \\
\hline Industry Agglomeration & 0.1761 & $* * *$ & 0.1743 & $* * *$ & 0.1858 & $* * *$ & 0.0444 & & 0.1196 & \\
\hline & $(0.0320)$ & & $(0.0320)$ & & $(0.0322)$ & & $(0.2755)$ & & $(0.3173)$ & \\
\hline Export Intensity & 0.0166 & $* * *$ & 0.0163 & $* * *$ & 0.0176 & $* * *$ & -0.0203 & & -0.0117 & \\
\hline & $(0.0014)$ & & $(0.0014)$ & & $(0.0014)$ & & $(0.0124)$ & & $(0.0124)$ & \\
\hline Industry Growth & -0.0023 & & -0.0023 & & -0.0022 & & -0.0022 & & -0.0123 & \\
\hline & $(0.0016)$ & & $(0.0016)$ & & $(0.0016)$ & & $(0.0188)$ & & $(0.0198)$ & \\
\hline Foreign Share & 0.0532 & $* *$ & 0.0525 & $* *$ & 0.0530 & $* *$ & 0.2376 & & -0.0814 & \\
\hline & $(0.0228)$ & & $(0.0228)$ & & $(0.0230)$ & & $(0.1746)$ & & $(0.19269$ & \\
\hline Industry Dummies & YES & & YES & & YES & & YES & & YES & \\
\hline $\mathrm{N}$ & 660457 & & 660457 & & 652229 & & 8228 & & 10045 & \\
\hline $\mathrm{R}^{2}$ & 0.2758 & & 0.2759 & & 0.2776 & & 0.2655 & & 0.3116 & \\
\hline
\end{tabular}


By Celeste Amorim Varum and Vera Rocha. Accepted for publication by International Business Review. (under revision).

Table 3. Turnover growth estimation results

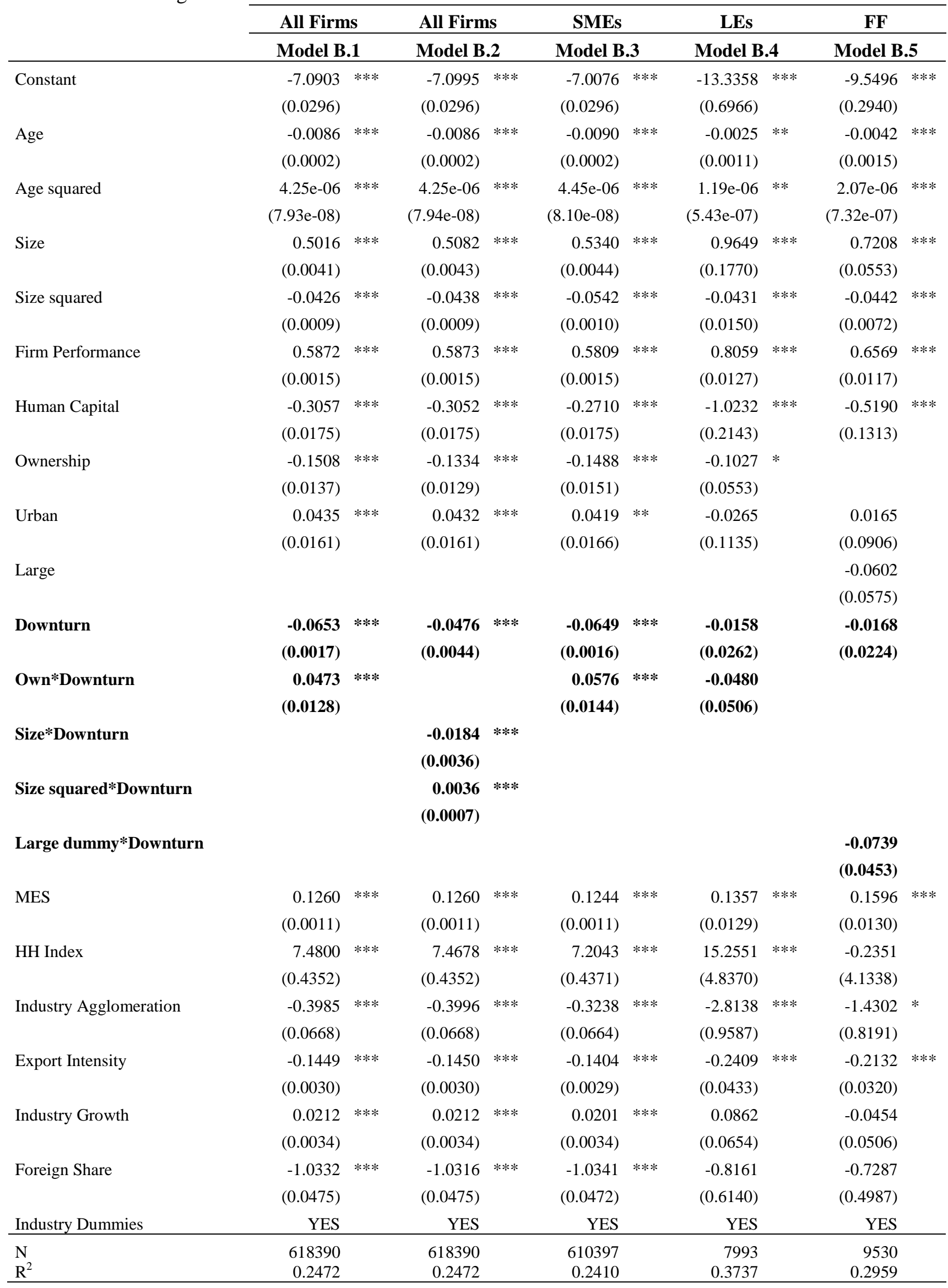


By Celeste Amorim Varum and Vera Rocha. Accepted for publication by International Business Review. (under revision).

As for employment growth, size is significant to differentiate firms during downturns. We found a U-shaped relationship between size and turnover growth under economic recessions. Until firms reach a certain threshold of size, their turnover growth may be strongly hit by economic slowdowns, becoming more resistant to sales' contraction as they grow big. However, as for employment growth, firm size is more significant within the group of DFs and does not significantly differentiate firms within the sample of FFs.

Table 4 summarizes our main empirical results ${ }^{12}$.

Table 4. Summary of empirical results

\begin{tabular}{llcc} 
& & \multicolumn{2}{c}{ Growth Measure } \\
\cline { 2 - 4 } & Sample & Employment Growth & Turnover Growth \\
\hline \multirow{2}{*}{ Foreign Ownership effect during crises } & All Firms & n.s. & + \\
& SMEs & n.s. & + \\
& LEs & n.s. & n.s. \\
\hline \multirow{2}{*}{ Firm Size effect during crises } & All Firms & - & $\cup$ \\
& FF & n.s. & n.s. \\
\hline
\end{tabular}

Note: (-): significant negative effect; (+) significant positive effect; n.s.: not significant.

\section{CONCLUSION}

In this paper we address an important, timely and still scarcely explored topic - the comparative dynamics of foreign and domestic firms during crisis, in order to assess whether foreign affiliates are more able to overcome the adversities and thus act as a stabilizer agent in host economies. Available firm-level studies have provided mixed and ambiguous results and have typically been based on the context of the Asian financial crisis of 1997-1998, dealing with firms' performance both during and after crisis.

Our results are based on an empirical setting where MNEs search mainly for a low-cost export base and, to a less extent, to expand their market. We analysed in specific the case of a small open economy hit by two recessions mainly driven by international developments. The

\footnotetext{
${ }^{12}$ As a robustness check of our results, we repeated the previous empirical analysis for the sub-periods 1988-2000 (comprising the recession of 1991-1993) and 1994-2006 (comprising the recession of 2001-2003). The results were not significantly different from those obtained for the global period 1988-2007, being available upon request.
} 
By Celeste Amorim Varum and Vera Rocha. Accepted for publication by International Business Review. (under revision).

recessions identified in the Portuguese economy during 1988-2007 impacted negatively on firms' employment growth and turnover growth rates. When we control for firm and industry characteristics, job losses in MNEs during both recessions were not significantly different from that of indigenous firms, but at turnover level foreign firms seem to have reacted better. Their organizational, managerial and technological advantages, adding to advantages of multinationality probably allowed them to cut operations (employment) and to smooth the decline in demand by screening and exploiting the markets globally.

Beyond the foreign ownership effect, we show that firm size matters to explain domestic firms' growth, exerting significant negative effects on firms' employment growth and non-linear effects on turnover growth throughout recessions. Regarding employment growth, large firms are the ones registering greater job losses. SMEs' turnover appears to be more severely affected by downturns while very large firms may have knowledge advantages to exploit markets, registering better performance in terms of turnover.

By using the Portuguese case as empirical setting, our study adds to the existing literature, as from the best of our knowledge, no previous study explored the potential effects arising from MNEs' presence in Portugal under a crisis context. Due to data limitations we could not control specifically for firms' exporting behaviour neither for the parent country of the foreign affiliates. Nonetheless, we accounted for the export intensity of the industry in an attempt to overcome the data limitation. Future research is encouraged to explore further ways of controlling for other relevant characteristics of foreign firms. The study explores two measures of performance. A natural extension to our study would be to investigate the ownership effect over survival and exit risk.

For policy, our results do not contest the option for active FDI attraction policies. As regards the evaluation of the potential advantages arising from MNEs' presence during economic slowdowns, the results indicate that MNEs do not exert a disturbing effect on host 
By Celeste Amorim Varum and Vera Rocha. Accepted for publication by International Business Review. (under revision).

economy employment during crisis and that may even contribute to smooth the declines in turnover. What seems crucial is the role of host governments in restoring foreign investors' confidence about the future and showing that the crisis may also be an opportunity to reorganize themselves and become more efficient, rather than just a threat.

\section{References}

Álvarez, R., Görg, H. (2007). Multinationals as stabilizers?: economic crisis and plant employment growth, Central Bank of Chile, Working Paper No. 412.

Álvarez, R., Görg, H. (2009). Multinationals and plant exit: evidence from Chile, International Review of Economics and Finance, 18, 45-51.

Athukorala, P. (2003). FDI in crisis and recovery: lessons from the 1997-1998 Asian crisis, Australian economic Review, 43, 197-213.

Bank of Portugal (2009a). A Economia Portuguesa em 2008, Economic Bulletin, Spring 2009.

Bank of Portugal (2009b). Perspectivas para a Economia Portuguesa: 2009-2011, Economic Bulletin, Winter 2009.

Barbosa, N., Louri, H. (2005). Corporate performance: does ownership matter? A comparison of foreign- and domestic-owned firms in Greece and Portugal, Review of Industrial Organization, 27, 1, 73-102.

Bamiatzi, V., Bozos, K., Nikolopoulos, K. (2010). On the predictability of firm performance via simple time-series and econometric models: evidence from UK SMEs, Applied Economic Letters, 17, 3, 279-282.

Barbosa, N., Guimarães, P., Woodward, D. (2004). Foreign entry in an open economy: the case of Portugal, Applied Economics, 36, 5, 465 - 472.

Belderbos, R., Zou, J. (2007). On the growth of foreign affiliates: multinational plant networks, joint ventures and flexibility, Journal of International Business Studies, 38, 7, 1095-1112.

Berry, A., Rodriguez, E., Sandee, H. (2001). Small and Medium Enterprise Dynamics in Indonesia, Bulletin of Indonesian Economic Studies, 37, 3, 363-8.

Blalock, G., Gertler, P., Levine, D. (2005). Investment following a financial crisis: does foreign ownership matter?, Mimeo, Cornell University.

Cardoso, V. (2008). Foreign multinationals and domestic companies in Portugal: are there significant performance gaps?, Master Thesis presented to Faculty of Economics, University of Porto: Portugal.

Caves, R. (1996). Multinational enterprise and economic analysis ( $2^{\text {nd }}$ ed.). Cambridge: Cambridge University Press.

Chung, C., Beamish, P. (2005). The impact of institutional reforms on characteristics and survival of foreign subsidiaries in emerging economies, Journal of Management Studies, 42, $1,35-62$. 
By Celeste Amorim Varum and Vera Rocha. Accepted for publication by International Business Review. (under revision).

Coad, A. (2009). The growth of firms: a survey of theories and empirical Evidence (New Perspectives on the Modern Corporation), Cheltenham: Edward Elgar Publishing

Desai, M., Foley, C., Forbes, K. (2004). Financial constraints and growth: multinational and local firm responses to currency crises, NBER Working Papers 10545. Cambridge, MA.: National Bureau of Economic Research.

Dunne, P., Hughes, A. (1994). Age, size, growth and survival: UK companies in the 1980s, Journal of Industrial Economics, 42, 2, 115-140.

Dunning, J. (1988). The eclectic paradigm of international production: A restatement and some possible extensions, Journal of International Business Studies, Spring: 1-31.

Dunning, J., Lundan, S. (2008). Multinational enterprises and the global economy ( ${ }^{\text {nd }}$ ed.). Cheltenham: Edward Elgar.

Edgington, D., Hayter, R. (2001). Japanese direct foreign investment and the Asian financial crisis, Geoforum, 32, 103-120.

Evans, D. (1987). The relationship between firm growth, size and age: estimates for 100 manufacturing industries, Journal of Industrial Economics, 35, 4, 567-581.

Flamm, K. (1984). The volatility of offshore investment, Journal of Development Economics, $16,231-248$.

Forbes, K. (2002). How do large depreciations affect firm performance?, NBER Working Papers 9095. Cambridge, MA.: National Bureau of Economic Research.

Fukao, K. (2001). How Japanese subsidiaries in Asia responded to the regional crisis - an empirical analysis based on the MITI survey. In T. Ito \& A. Krueger (Eds.), Regional and global capital flows: macroeconomics causes and consequences (pp. 267-310). NBER-EASE Volume 10, NBER Books.

Gao, T., Eshaghoff, T. (2004). MNCs' preferred responses to the Argentine financial crisis: a classification and empirical investigation, Latin American Business Review, 5, 1, 23-44.

Görg, H., Strobl, E. (2003).'Footloose' multinationals?, The Manchester School, 71, 1, 1-19.

Greene, W. (2008). Econometric Analysis (6 ${ }^{\text {th }}$ ed.). NY: Prentice Hall.

Guimarães, P., Figueiredo, O., Woodward, D. (2000). Agglomeration and the location of foreign direct investment in Portugal, Journal of Urban Economics, 47, 115-135.

Hult, G., Ketchen Jr., D., Griffith, D., Chabowski, B., Hamman, M., Dykes, B., Pollitte, W., Cavusgil, S. (2008). An assessment of the measurement of performance in International Business research, Journal of International Business Studies, 39, 1064-1080.

Hymer, S. (1976). The international operations of national firms: a study on direct foreign investment. Cambridge (MA): MIT Press.

Karlsson, S., Lundin, N., Sjöholm, F., He, P. (2009). Foreign firms and Chinese employment, The World Economy, 31, 1, 178-201.

Lee, S., Makhija, M. (2009). Flexibility in internationalization: is it valuable during an economic crisis?, Strategic Management Journal, 30, 537-555.

Legewie, J. (1999). Manufacturing strategies for Southeast Asia after the crisis: European, US and Japanese firms, Business Strategy Review, 10, 4, 55-64.

Lipsey, R. (2001). Foreign investment in three financial crisis, NBER Working Papers 8084. Cambridge, MA.: National Bureau of Economic Research. 
By Celeste Amorim Varum and Vera Rocha. Accepted for publication by International Business Review. (under revision).

Markusen, A., Nesse, K. (2007). Institutional and political determinants of incentive competition: reassessing causes, outcomes, remedies. In A. Markusen (ed.), Reining in the Competition for Capital: International Perspective, W. E. Upjohn Institute for Employment Research: Kalamizoo Michigan, pp. 1-41.

McAleese, D., Counahan, M. (1979). Stickers or Snatchers? Employment in multinational corporations during recessions, Oxford Bulletin of Economics and Statistics, 41, 345-358.

Min, B., Rhim, J., Friesner, D., Cashel-Cordo, P. (2007). On the behavior of global multinational enterprises during the 1997 Asian financial crisis, The Journal of Economic Development and Business Policy, 1, 52-89.

Narjoko, D., Hill, H. (2007). Winners and losers during a deep economic crisis: firm-level evidence from Indonesian manufacturing, Asian Economic Journal, 21,4, 343-368.

OECD (1994). OECD reviews on foreign direct investment - Portugal, OECD Reviews on Foreign Direct Investment, April.

Oxelheim, L., Ghauri, P. (2004). European Union and the Race for Foreign Direct Investment in Europe, Elsevier: Oxford UK.

Pfaffermayr, M., Bellak, C. (2002). Why foreign-owned firms are different: a conceptual framework and empirical evidence for Austria, HWWA Discussion Paper 115, Hamburg: Hamburg Institute of International Economics.

Poon, J., Thompson, E. (2001). Effects of the Asian financial crisis on transnational capital, Geoforum, 32, 121-131.

Takii, S., Ramstetter, E. (2005). Multinational presence and labour productivity differentials in Indonesian manufacturing, 1975-2001, Bulletin of Indonesian Economic Studies, 41, 2, 221-242.

Tan, H., See, H. (2004). Strategic reorientation and responses to the Asian financial crisis: the case of the manufacturing industry in Singapore, Asia Pacific Journal of Management, $21,189-211$.

Tavares, A. T. (2002). Multinational subsidiary evolution and public policy: two tales from the European periphery, Journal of Industry, Competition and Trade, 2, 3, 195-213.

Wang, H., Huang, H., Bansal, P. (2005). What determined success during the Asian economic crisis? - The importance of experiential knowledge and group affiliation, Asia Pacific Journal of Management, 22, 89-106.

Zaheer, S. 1995. Overcoming the liability of foreignness, The Academy of Management Journal, 38, 2, 341-363. 
By Celeste Amorim Varum and Vera Rocha. Accepted for publication by International Business Review. (under revision).

\section{Appendix}

\section{Variable Definitions}

\begin{tabular}{|c|c|c|c|}
\hline \multicolumn{2}{|c|}{ CATEGORY } & VARIABLES & DESCRIPTION \\
\hline \multirow{2}{*}{\multicolumn{2}{|c|}{$\begin{array}{l}\text { Dependent } \\
\text { Variables }\end{array}$}} & Employment Growth & Ln $\left(\right.$ Employment $\left.{ }_{t}\right)-$ Ln $\left(\right.$ Employment $\left._{\mathrm{t}-1}\right)$ \\
\hline & & Turnover Growth & Ln $\left(\right.$ Turnover $\left._{t}\right)-$ Ln $\left(\right.$ Turnover $\left._{t-1}\right)$ \\
\hline \multirow{6}{*}{\multicolumn{2}{|c|}{$\begin{array}{c}\text { Main Variables } \\
\text { of Interest }\end{array}$}} & Ownership & Dummy $=1$ if, at least, $50 \%$ of the capital is held by foreign investors, 0 otherwise. \\
\hline & & Large dummy & Dummy $=1$ if the firm is large-sized (i.e. it is not a SME), 0 otherwise. \\
\hline & & Own*Downturn & Interaction variable measuring the effect of being a FF during downturns \\
\hline & & Size*Downturn & Interaction variable between firm size and downturn periods \\
\hline & & Size $^{2 *}$ Downturn & Interaction variable between the square of firm size and downturn periods \\
\hline & & Large*Downturn & Interaction variable measuring the effect of being a large-sized firm during downturns \\
\hline \multirow{15}{*}{$\begin{array}{c}\text { Other } \\
\text { variables }\end{array}$} & \multirow{7}{*}{ 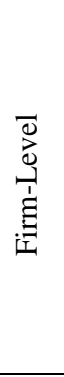 } & Age & Number of years since the entry of the firm ${ }^{1}$ \\
\hline & & Age squared & Squared number of years since the entry of the firm \\
\hline & & Size & Ln (number of employees) \\
\hline & & Size squared & Squared value of Ln (number of employees) \\
\hline & & Firm Performance & Operational Performance measured through the log of the ratio Turnover/Employment \\
\hline & & Human Capital & Ratio Number of workers with a college degree/Total number of workers \\
\hline & & Urban & Dummy $=1$ if the firm operates in the districts of Porto or Lisbon and 0 otherwise \\
\hline & \multirow{7}{*}{ 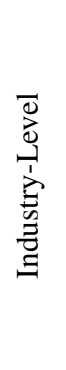 } & MES & Median of 2-digit industry's employment \\
\hline & & HH Index & Herfindhal Index - sum of the squared share of FF in total 2-digit industry's employment \\
\hline & & Industry Agglomeration & Share of 2-digit industry's employment in total Manufacturing employment \\
\hline & & Foreign Share & Share of FF's employment in total 2-digit industry's employment \\
\hline & & Export Intensity & Ratio 2-digit industry Exports/2-digit industry VAB \\
\hline & & Industry Growth & Ln (2-digit industry Employment $\left.t_{t}\right)-$ Ln (2-digit industry Employment $\left.t_{-1}\right)$ \\
\hline & & Industry Dummies & Dummy $=1$ for each 2-digit industry where the firm operates, 0 otherwise \\
\hline & 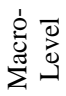 & Downturn & Dummy $=1$ for the years 1991, 1992, 1993, 2001, 2002, 2003, 2007 and 0 otherwise \\
\hline
\end{tabular}

${ }^{1}$ No data for the foundation year was available before 1994. As a result, for the computation of Firm Age, we proxied the foundation year through the year of admission of the former worker for each firm. 